\title{
Industrial Scale Production of Palm Super Olein Using Modified and Innovative Dry Fractionation Technique
}

\author{
Hanafy A. Hashem ${ }^{1}$, Nasser E.Abd- Ellh ${ }^{1}$, Ghareeb A. Abd-Eltawab ${ }^{2}$ and Adel \\ G. Abdel-Razek*3 \\ ${ }^{1}$ Department of Food Science and Technology, Faculty of Agric., Al-Azhar University, Cairo, Egypt. \\ ${ }^{2}$ Ajwa for Food Industries Company-Attaka-Suez-Egypt. \\ ${ }^{3}$ Department of Fats and Oils, National Research Centre, Dokki 12622, Cairo, Egypt.
}

\begin{abstract}
DALM oil is vastly utilized in food processing, principally attributed to the physical and chemical characteristics that make it especially suitable for many food applications. The present work aimed to make attempts at finding a method for producing a novel palm super olein (PSO) through a new modified industrial application process. Pure and modified palm olein (palm olein $+5 \%$ palm oil) with an iodine value of 56.5 and 56.4 respectively were crystallized with a controlled cooling system and convenient stirring process. The slurry was then fractionated by dry fractionation either by conventional method at $17^{\circ} \mathrm{C}$ or by innovative method at $16.6^{\circ} \mathrm{C}$. By varying the fractionation conditions used, a range of super olein and palmmid fractions with different chemical and physical properties could be obtained. The Rancimat method was utilized to determine the oxidative stability of various palm oil fractions. Also, the physical and the chemical parameters of the different fractions were evaluated, whereas fatty acid composition was determined by GLC. The obtained PSO by fractionation using modified olein at $16.6{ }^{\circ} \mathrm{C}$ gave PSO with MP $9{ }^{\circ} \mathrm{C}$ and also enhanced the cloud point, melting point and iodine value. It is recommended that the modified and innovative dry fractionation process, performed in large-scale, can be taken as a model for improving palm oil fractionation.
\end{abstract}

Keywords: Palm olein, palm super olein, Innovative dry fractionation, Palm-mid fractions, Oxidative stability.

\section{Introduction}

The fractionation of vegetable oils is one of the main modification procedures used by the industry to give it the necessary elasticity for the proper use of palm oil and its fractions in the numerous fattyfoods[1]. The fractionation technique is the major modern modification method utilized especially for palm oil separation[2, 3]. It is worthy to mention that, palm oil production is still increasing rapidly in recent years and turn into the world's most-produced and consumed oil[4]. In edible oil manufacturing, fractionation method depends on cooling of palm oil under control system, thereby induces a fractional crystallization. The liquid form (olein) is subsequently isolated from the solid form (stearin) using a filtration system. Palm stearin, rich in solid fat content, is suitable as a component of the specialty fats important in a bakery, confectionery, and pastries products. Fractionation is thus set to fit the predominant modification method to produce saturated fats with high melting point free from trans fatty acids[5].

Fractionation on the production level can be categorized into three classes, dry, detergent, and solvent fractionation, based on the proceeding and crystallization methods. These techniques have been utilized in manufacturing cooking and frying oils from palm oil, namely olein and super olein were evaluated by many authors[6,7]. Dry fractionation is a simple physical separation method which fulfils recent growing environmental and health interests. Dry fractionation technology has shown good progress due to modern improvements in melt crystallization and application of membrane filter press[8]. At the same time, the dry fractionation is an economical and safe technology. The cloud formation in palm olein products during transportation as well as storage in cold weather is an important issue. So, the turbidity is formed due to crystallization of palm olein during winter weather[9]. 
Actually, there is nothing improper regarding the oil quality, but it is important to prohibit crystallization because consumers consider that turbidity of an oil is a kind of adulteration. The crystals appear in palm olein at lower temperatures are mainly due to diglycerides content. The clouding problem in palm olein has been solved to a certain extent by blending it with soft oils or adding additives or using a double fractionation method [9]. Thus, it was necessary to search for methods to improve palm olein fractionation to achieve sufficient removal of high-meltingpoint components. The functionality of palm super olein to achieve specialty oils reveal a market for new high-quality productivity like fractionated products. Recently, the industrial edible oil sector has turned into a significant field for a technological R\&D. Furthermore, optimization of the crystallization situations for an utmost retention of natural characteristics without affecting the quality of the palm oil is a serious challenge. Therefore, the topic which will be discussed in this study is strongly related and useful to the edible fats and oils production sector. It is well known that the fractionation conditions can be modified for the production of a demand specific fraction for a special application[10, 11]. It was objective to carry out the industrial scale of dry fractionation by using two new modified methods different from the conventional one. Also, it was planned to try achieving extraordinary physical and chemical characteristics of PSO. Furthermore, it was a target to prevent cloud forming as far as possible to ameliorate PSO and its mixtures to make it more appropriate for cold weather.

\section{Materials and Methods}

\section{Materials}

All samples, refined, bleached and deodorized (RBD) palm olein (POL), MP $23^{\circ} \mathrm{C}$ and IV 56, as well as RBD palm oil (PO) with MP $37^{\circ} \mathrm{C}$ and IV 52 , used in the present study were kindly obtained from Ajwaa Factory for Food Industries, Attaka, Suez, Egypt. Also, all experiments and processing trials were carried out in a plant of 176 ton capacity, in the same factory. This factory is interested in edible oil processing and palm oil fractionation. All solvents of HPLC grade, from Sigma-Aldrich (St. Louis, MO, USA). FAME standards was purchased from Supelco (Bellefonte, PA, USA).

\section{Methods}

Experimental treatments

The industrial-scale experiments in crystallization process were carried out in four trials as shown in Fig. 1.

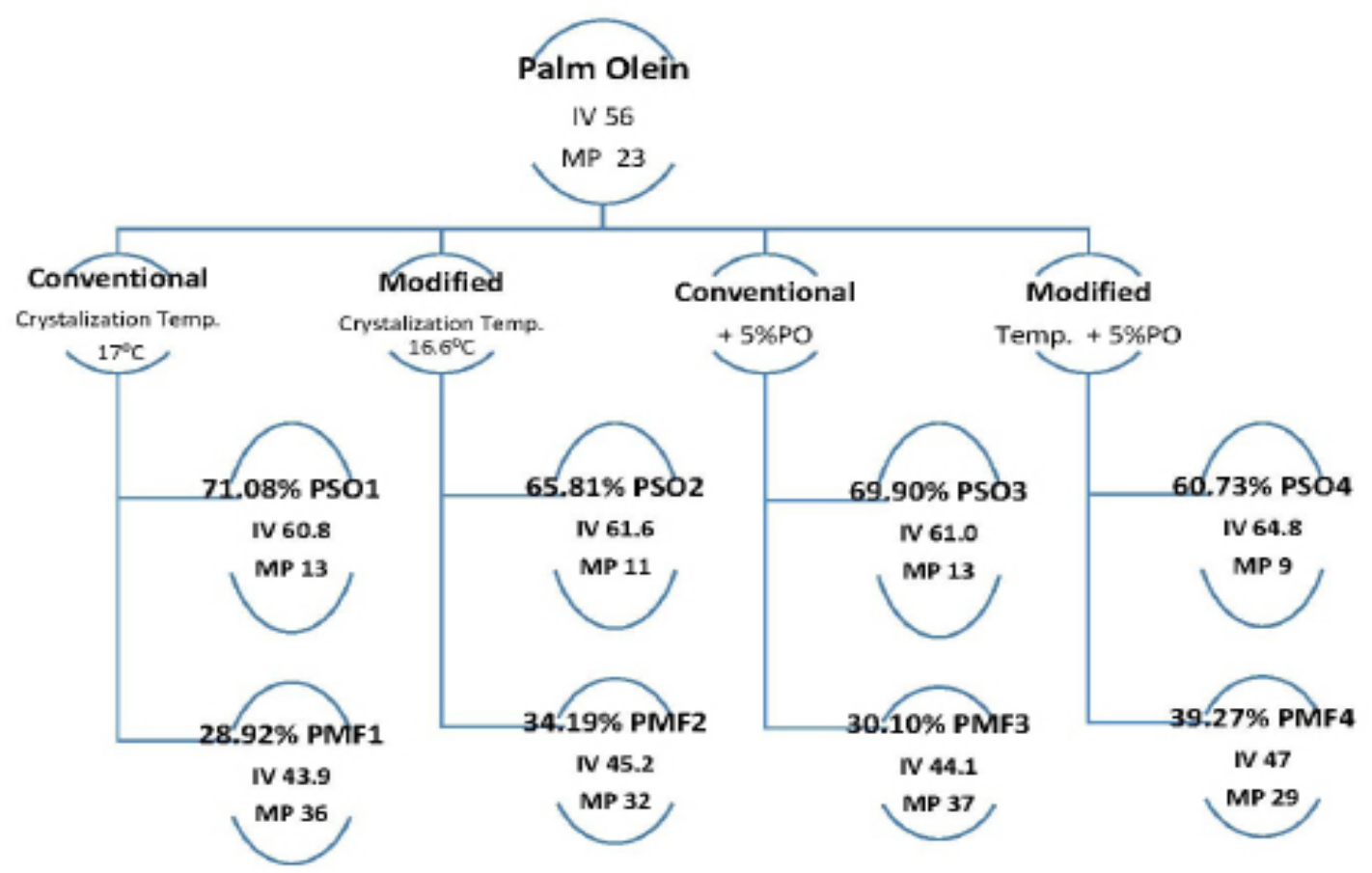

Fig. 1. Flow chart of palm olein fractionation of LF (SPO) and SF (PMF) produced by modified and conventional fractionation methods.

Egypt.J.Chem. 61, No.1 (2018) 
P S O: palm super olein P M F: palm mid fraction LF: Liquid fraction SF: Solid fraction

\section{Dry fractionation of palm olein}

A fractionation plant (Tirtiaux unit, Belgium) include 4 crystallizers with a capacity of 44 ton each in which the RBD POL was charged, stirred and kept at the required temperature. The crystallizers were provided with agitators, cooling serpentines and double cooling wall.

Dry fractionation (without any solvent), applied to PO, involving the fractional crystallization of a solid phase and its separation from the liquid phase. Thus POL was fractionated by conventional method at $17^{\circ} \mathrm{C}($ Exp. I). This dry fractionation method was compared to modified method (adopted in this work) using fractionation temperature at $16.6^{\circ} \mathrm{C}$ (Exp. II). In addition, in Exp. III and Exp. IV, 5\% PO was added to POL as trials to enhance the seeding during the crystallization process. The products, namely, PSOs (PSO1, 2, 3 \& 4 liquid fractions) and palmmid fractions (PMF1, 2, $3 \& 4$ solid fractions) were obtained (Fig. 1).

Conventional method (heating at $55^{\circ} \mathrm{C}$ ) while modified method (heating at $45^{\circ} \mathrm{C}$ and with addition of $5 \%$ palm oil) were adopted. In both methods the heating was carried out for one hour. After that the oil was cooled to $17^{\circ} \mathrm{C}$ and $16.6^{\circ} \mathrm{C}$ under controlled conditions with cold water for about 24 hours for conventional and modified methods respectively. The filtration was followed after $4 \mathrm{~h}$ using a batch belt filter. The cooling process of oil was controlled by a circulating unit and general control unit as illustrated in Fig.2.

\section{Traditional and modified cooling curve of palm olein}

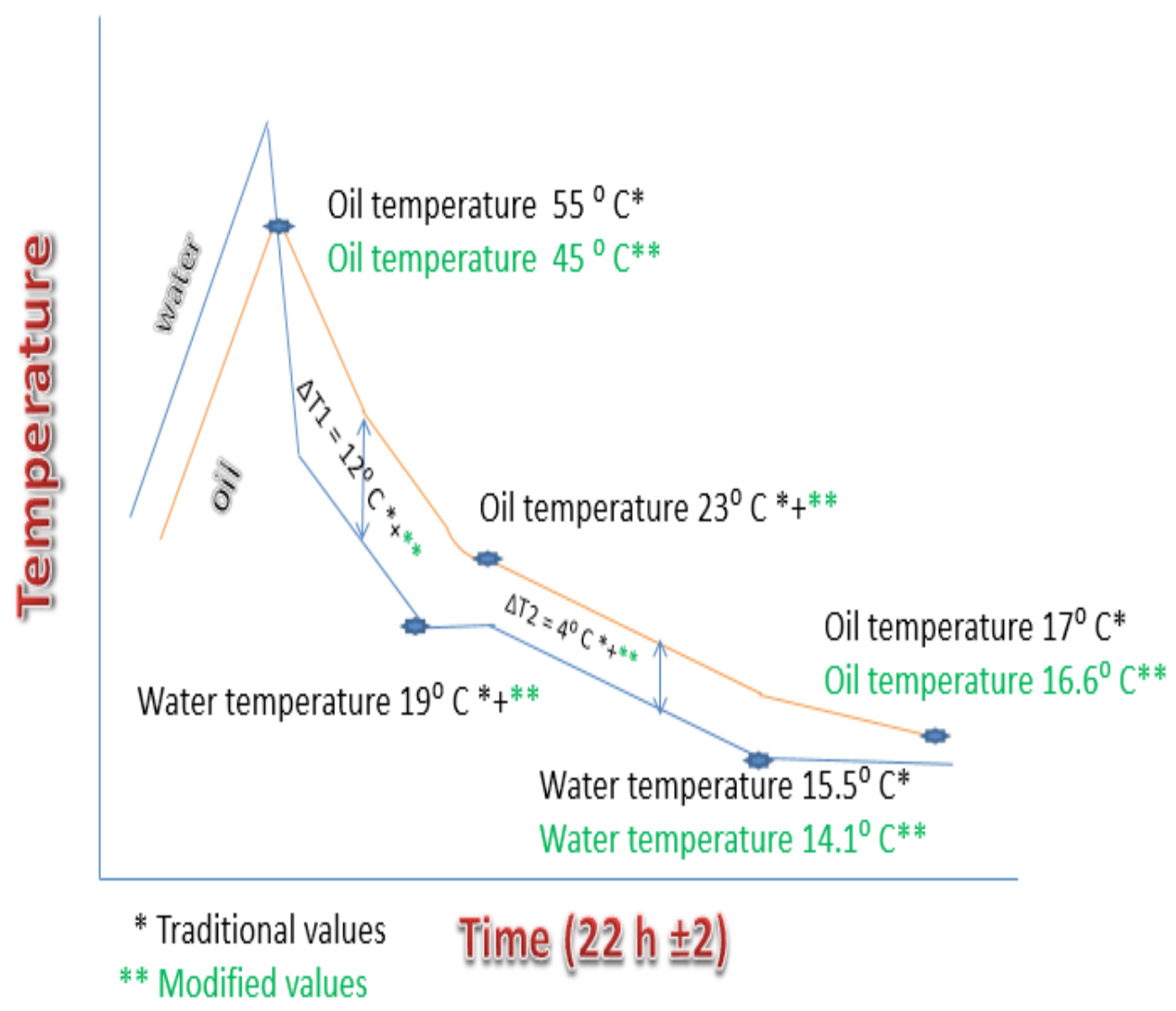

Fig. 2. Modified and traditional cooling curve of palm olein. 


\section{Analytical methods}

Determination of physical properties

Color (C), density (D), refractive index (RI), melting point (MP) via slip point method, cloud point $(\mathrm{CP})$ and cold test $(\mathrm{CT})$ of the investigated oil samples were determined according to AOCS (2000) [12].

Determination of chemical properties of palm olein and its fractions

Free fatty acids \% (FFA \%) as oleic acid, peroxide value ( $\mathrm{PV}$ meq $\mathrm{O}_{2} / \mathrm{kg}$ oil) and iodine value (IV) of the studied oil samples were determined according to the methods described by AOCS (2000) [12].

\section{Oxidative stability}

The induction period (IP) measurements were carried out on the investigated oil samples. IP indicates the oil resistance to oxidative rancidity, and then the shelf life of the oil can be estimated. The IP, as oxidative stability index, of the tested oils were measured by an automated Rancimat (MetrohmUd. CH- 9100 Herisau, Switzerland, model 679) at $100^{\circ} \mathrm{C}$, comprises of the control unit and the wet section containing six reaction vessels, according to the method described by AOCS, 1997 [13]. acids

Gas chromatographic analysis of the fatty

Fatty acids methyl esters (FAME) were prepared according to AOCS official method and assessed by GC [14]. Diluted FAME were separated on a HP 5890 series II (Hewlett Packard, Palo Alto, USA) equipped with an innowax capillary column $(30 \mathrm{~m} \quad 0.20 \mathrm{~mm} 0.20$ $\mathrm{mm}$ ) and FID (FID). Hydrogen was used as the carrier gas at flow rate of $1.5 \mathrm{ml} \mathrm{min}-1$. The column temperature was isotherm $\left(210^{\circ} \mathrm{C}\right)$. Detector and injector temperatures were set at $240^{\circ} \mathrm{C}$. Fatty acids were identified by comparison of the retention times with authentic standards and the results were calculated as percentage of total fatty acids.

\section{Statistical analysis}

The results were expressed as the mean \pm SE. Results were analyzed statistically using the oneway analysis of variance ANOVA followed by Duncan's test. In all cases $\mathrm{p}<0.05$ was used as the criterion of statistical significance.

\section{Results and Discussion}

A fractionation method depends on cooling

Egypt.J.Chem. 61, No.1 (2018) of PO under control system, thereby induce a fractional crystallization. The liquid part (olein) is thereafter separated from the solid part (stearin) by the filtration system. In the present work, the innovative developed method (on industrial large-scale) was done, as a trial, to improve the technology of crystallization and dry fractionation of POL.

\section{Physical properties of $P O L$ and its fractions}

The major physical properties of original POL and its fractions obtained at $17^{\circ} \mathrm{C}$ (PSO1\& PMF1) and modified fraction at $16.6^{\circ} \mathrm{C}$; (PSO2, PMF2). Another new modified was blend between POL + $5 \% \mathrm{PO}$ and its fractions at $17^{\circ} \mathrm{C}$ (PSO3, PMF3) and at $16.6^{\circ} \mathrm{C}$ (PSO4, PMF4) were shown in Table 1. Concerning the yields ratio of PSO: PMF, the values 71.08: 28.92 in (fractionation 1), 65.81: 34.19 in (fractionation 2), 69.90: 30.10 in (fractionation 3) and 60.73: 39.27 in fractionation 4 were obtained (Table 1).

From the results in Table 1 it could be noticed that the yields of PSO as liquid fractions (LF) were higher than that of PMF as a solid fraction (SF). This might be attributed to the major unsaturated fatty acid components in POL. Meanwhile, the fractionation at high temperature leads to formation of fewer crystals, hence reducing the amount of PMF. However, by decreasing the fractionation temperatures from 17 to $16.6{ }^{\circ} \mathrm{C}$ and in presence of $5 \% \mathrm{PO}$, the yields of PSO were decreased while PMF yields were increased. These results agree with that recorded by Calliauw et al., and Ablatip et al., $[15,16]$ they found that the SF yield is strongly dependent on crystallization temperature, as crystallization temperature increased, the SF yield decreased and vice versa.

Similar to pure POL (3.7R/Y) (Table 1). The color value of PSO samples obtained by different dry fractionation methods showed a small variation, amounting to 3.8 in PSO1, PSO3; 4.1 and 4.4 in PSO2 and PSO4, respectively. Also, it was found that a relatively small variation in color of PMF1, PMF2, PMF3 and PMF4 (3.1, $3.2,3.1$ and 3.4 respectively). These results are in harmony with those of Kellens et al., [17] as they reported that the pigment concentrated in LF.

The density results of the modified and traditional samples were recorded in Table 1. It was found that the density of pure POL compared to the modified one (with 5\% PO) were 0.9098 and 0.9064 respectively. The densities of modified 
treated sample amounted to 0.9133 and 0.8998 which are higher than that of the conventional treatment $(0.9121$ and 0.8996$)$ in LF and SF respectively. Concerning the modified blends, it was noticed that the densities of modified treatment PSO4 and PMF4 were slightly higher than that of the conventional treatment. Generally it was noticed that the densities of LF's were higher than that of SF's amounted to 0.9121, $0.9133,0.9125$ and 0.9151 in PSO1, PSO2 PSO3 and $\mathrm{PSO} 4$, respectively, in comparison to 0.8996 , $0.8998,0.8997$ and 0.9031 for PMF1, PMF2, PMF3 and PMF4, respectively.

Concerning refractive index, no clear difference was observed in the investigated oil samples. It was ranged from 1.4554 to 1.4598 (Table 1). It was noticed that the MP of PSO2 \& PMF2 (11 \& 32) lower than that in PSO1 \& PMF1 $\left(13^{\circ} \mathrm{C} \& 36^{\circ} \mathrm{C}\right)$. From Table 1 it can be observed that the melting point of different fractions (PSO and PMF) was dependent on crystallization temperatures. While the addition of PO to POL without decrease of crystallization temperatures has no significant effect on melting point of $\mathrm{PSO} 3$ comparing to PSO1 as well as PMF3 comparing to PMF 1 fraction. The addition of PO to POL at modified of crystallization temperature $\left(16.6^{\circ} \mathrm{C}\right)$ improved separation efficiency and lead to a decrease of PSO and PMF melting points. This may be due to the presence of high melting point saturated triglycerides (present in the added PO), which helps nucleation and crystallization rates. Whereas lowering the crystallization temperature to $16.6^{\circ} \mathrm{C}$ helps crystals to grow. These results are in harmony with the finding of Omar et al., [8] who reported that the addition of specific fatty materials to palm oil at different ratios improved the nucleation and crystallization rates. While Arnaud Collignan[18] studied the effect of temperature on the characteristics of animal fat fractionation.

Cloud point is a test to determine the temperature at which the oil begins to cloud resulting from crystallization under controlled cooling condition. It was found that there was a significant variation in the value of cloud point of PSO fractions obtained by dry fractionation methods (Table 1). The modified crystallization temperature leads to decrease in cloud point of both PSO fractions from $6.5^{\circ} \mathrm{C}$ (PSO1) to $5.5^{\circ} \mathrm{C}$ (PSO2), in LF. The addition of $5 \% \mathrm{PO}$ to $\mathrm{POL}$ in classical fractionation temperature, the PSO3 fraction (LF) had the high cloud point $\left(6.5^{\circ} \mathrm{C}\right)$ comparing to the modified treatment, it decreased to $4^{\circ} \mathrm{C}$ (PSO4). These results are in agreement with those found by Zaliha et al., [19], who reported that lower crystallization temperatures, lead to lower cloud points of the fractions. Also, Deffense[20] reported that the main objective of fractionation is to obtain POL with low cloud point to be suitable as a cooking oil. Concerning the cold test, it gave positive results in both conventional and modified treatments.

The results of FFA, PV, IV\& IP of modified and conventional POL fractionation methods were shown in Table 2.

The results of FFA \%, show nearly no significant variations in original, conventional and modified samples. Concerning, the PV of the original, conventional and modified samples (LF $\& \mathrm{SF}$ ), it ranged from 3.33 to $3.80 \mathrm{meq} \mathrm{O}_{2} / \mathrm{kg}$.

From the results recorded in Table 2, it was found that the increase in the amount of unsaturation character (expressed as IV) at modified temperature was noticed and amounted to 61.6 for PSO2 and 45.2 for PMF2 than that of the original (56.5) and PSO1 60.8 \& PMF1, 43.9. In another case of modified treatment, the addition of $5 \% \mathrm{PO}$ at crystallization temp. $\left(16.6^{\circ} \mathrm{C}\right)$ leads to increase in IV reached to 61.0 for PSO3 and 64.8 for $\mathrm{PSO} 4$ at $16.6^{\circ} \mathrm{C}$ and $17^{\circ} \mathrm{C}$ respectively. In modified SF (PMF4), IV amounted to 47.0 in comparison to 44.1 in conventional PMF3. The increase in IV of PSO fractions due to the increase of MUFA and PUFA groups. These results are in agreement with those found by Zaliha et al., [19] as they reported that, the iodine values of liquid fractions increased as crystallization temperatures decreased. Dang et al., [21] reported that the crystallization temperature has a great function in the operation of oil crystallization. The crystallization process under various cooling conditions lead to increase in cooling rate and decrease in particle size, which display that the cooling rate plays an influential role in the efficiency of nucleation.

It is worthy to mention that the addition of palm oil to palm olein (modified palm olein) at $17^{\circ} \mathrm{C}$ (without decrease of crystallization temperature) has no significant effect on the CP, MP and IV of PSO fraction. Also, a clear good relation between IV and CP of the oil fraction at the different crystallization temperatures appeared. Thus, super palm olein samples with high IV had low cloud points, in comparison to SPO samples with low IV had high CP. In addition, fractionation of 
POL is closely associated with its chemical and physical properties.

Oxidative stability of investigated palm olein and its fractions

The induction period (IP) measured at $100^{\circ} \mathrm{C}$ was carried out on the oil fractions in order to provide a quick indication of the trends of the heated samples towards resistance to oxidation. From the data recorded in Table 2, it was noticed that the IP in the Rancimat test of super olein samples showed high oxidative stability but almost similar for LF (38.3 inPSO1, PSO2, PSO3 and 38.1 in PSO4). These results are in accordance with that reported by many authors $[6,7,22]$ they reported that the long induction period of POL is comparable with that of other vegetable oils (sunflower-soybean and rapeseed), owing to their inherent composition and to the presence of vitamin $\mathrm{E}$ (tocopherols and tocotrienols) in $\mathrm{PO}$ which have a natural antioxidants efficiency. In

TABLE 1. Physical properties of LF`s (SPO) and SF`s (PMF) produced by modified and conventional fractionation methods.

\begin{tabular}{|c|c|c|c|c|c|c|c|}
\hline \multirow{2}{*}{ Characteristics } & & \multirow{2}{*}{$\begin{array}{c}\text { Original } \\
\text { POL } \\
\text { (Zero } \\
\text { time) }\end{array}$} & \multicolumn{2}{|c|}{ Original POL } & \multicolumn{2}{|c|}{$\begin{array}{l}\text { Modified Blend } \\
(\text { POL }+5 \% \text { PO) }\end{array}$} & \multirow{2}{*}{$\begin{array}{c}\text { Modified } \\
\text { Blend } \\
\text { (Zero time) }\end{array}$} \\
\hline & & & $\begin{array}{c}1 \\
\left(17^{\circ} \mathrm{C}\right)\end{array}$ & $\begin{array}{c}2 \\
\left(16.6^{\circ} \mathrm{C}\right)\end{array}$ & $\begin{array}{c}3 \\
\left(17^{\circ} \mathrm{C}\right)\end{array}$ & $\begin{array}{c}4 \\
\left(16.6^{\circ} \mathrm{C}\right)\end{array}$ & \\
\hline Yield (\%) & $\begin{array}{l}\text { P S O } \\
\text { P M F }\end{array}$ & - & $\begin{array}{l}71.08^{\mathrm{a}} \\
\pm 0.34 \\
28.92^{\mathrm{d}} \\
\pm 0.32\end{array}$ & $\begin{array}{l}65.81^{\mathrm{d}} \\
\pm 0.48 \\
34.19^{\mathrm{b}} \\
\pm 0.51\end{array}$ & $\begin{array}{l}69.90^{\mathrm{b}} \\
\pm 0.52 \\
30.10^{\mathrm{c}} \\
\pm 0.49\end{array}$ & $\begin{array}{l}60.73^{\mathrm{c}} \\
\pm 0.14 \\
39.27^{\mathrm{a}} \\
\pm 0.17\end{array}$ & - \\
\hline Color (R/Y) & P S O & $\begin{array}{c}3.7^{\mathrm{c}} \\
\pm 0.055\end{array}$ & $\begin{array}{c}3.8^{\mathrm{c}} \\
\pm 0.055 \\
3.1^{\mathrm{c}} \\
\pm 0.11\end{array}$ & $\begin{array}{c}4.1^{\mathrm{b}} \\
\pm 0.11 \\
3.2^{\mathrm{c}} \\
\pm 0.55\end{array}$ & $\begin{array}{c}3.8^{\mathrm{c}} \\
\pm 0.071 \\
3.1^{\mathrm{c}} \\
\pm 0.55\end{array}$ & $\begin{array}{c}4.4^{\mathrm{a}} \\
\pm 0.084 \\
3.4^{\mathrm{b}} \\
\pm 0.11\end{array}$ & $\begin{array}{c}3.7^{\mathrm{a}} \\
\pm 0.055\end{array}$ \\
\hline Density (g/ml) & P M F & $\begin{array}{c}0.9098^{b} \\
\pm 0.0003\end{array}$ & $\begin{array}{c}0.9121 \mathrm{a}^{\mathrm{b}} \\
\pm 0.0002 \\
0.8996^{\mathrm{c}} \\
\pm 0.0002\end{array}$ & $\begin{array}{c}0.9133^{\mathrm{a}} \\
\pm 0.0002 \\
0.8998^{\mathrm{c}} \\
\pm 0.0002\end{array}$ & $\begin{array}{c}0.9125^{\mathrm{a}} \\
\pm 0.0012 \\
0.8997^{\mathrm{c}} \\
\pm 0.0001\end{array}$ & $\begin{array}{c}0.9151^{\mathrm{a}} \\
\pm 0.006 \\
0.9031^{\mathrm{b}} \\
\pm 0.0001\end{array}$ & $\begin{array}{l}0.9064^{\mathrm{a}} \\
\pm 0.0003\end{array}$ \\
\hline $\begin{array}{l}\text { Refractive } \\
\text { index }\end{array}$ & P S O & $\begin{array}{l}1.4585^{\mathrm{a}} \\
\pm 0.0002\end{array}$ & $\begin{array}{c}1.4591^{\mathrm{c}} \\
\pm 0.0001 \\
1.4554^{\mathrm{c}} \\
\pm 0.0002\end{array}$ & $\begin{array}{c}1.4595^{\mathrm{c}} \\
\pm 0.0002 \\
1.4556^{\mathrm{c}} \\
\pm 0.0002\end{array}$ & $\begin{array}{c}1.4593^{\mathrm{c}} \\
\pm 0.0002 \\
1.4554^{\mathrm{c}} \\
\pm 0.0002\end{array}$ & $\begin{array}{c}1.4598^{\mathrm{b}} \\
\pm 0.0002 \\
1.4559^{\mathrm{b}} \\
\pm 0.0002\end{array}$ & $\begin{array}{l}1.4581^{\mathrm{a}} \\
\pm 0.0002\end{array}$ \\
\hline $\begin{array}{l}\text { Melting point } \\
\left({ }^{\circ} \mathrm{C}\right)\end{array}$ & $\begin{array}{l}\text { P S O } \\
\text { P M F }\end{array}$ & $\begin{array}{c}23^{\mathrm{a}} \\
\pm 0.26\end{array}$ & $\begin{array}{c}13^{\mathrm{b}} \\
\pm 0.33 \\
36^{\mathrm{b}} \\
\pm 0.32\end{array}$ & $\begin{array}{c}11^{\mathrm{c}} \\
\pm 0.13 \\
32^{\mathrm{c}} \\
\pm 0.41\end{array}$ & $\begin{array}{c}13^{\mathrm{b}} \\
\pm 0.32 \\
37^{\mathrm{d}} \\
\pm 0.5\end{array}$ & $\begin{array}{c}9.0^{\mathrm{d}} \\
\pm 0.36 \\
29^{\mathrm{e}} \\
\pm 0.15\end{array}$ & $\begin{array}{c}24^{\mathrm{a}} \\
\pm 0.26\end{array}$ \\
\hline $\begin{array}{l}\text { Cloud point } \\
\qquad\left({ }^{\circ} \mathrm{C}\right)\end{array}$ & $\begin{array}{l}\text { P S O } \\
\text { P M F }\end{array}$ & $\begin{array}{l}11.5^{\mathrm{a}} \\
\pm 0.16\end{array}$ & $\begin{array}{c}6.5^{\mathrm{b}} \\
\pm 0.071 \\
-\end{array}$ & $\begin{array}{c}5.5^{\mathrm{c}} \\
\pm 0.011 \\
-\end{array}$ & $\begin{array}{c}6.5^{\mathrm{b}} \\
\pm 0.005 \\
-\end{array}$ & $\begin{array}{c}4.0^{\mathrm{d}} \\
\pm 0.004 \\
-\end{array}$ & $\begin{array}{c}12^{\mathrm{a}} \\
\pm 0.16\end{array}$ \\
\hline Cold test & $\begin{array}{l}\text { P S O } \\
\text { PM F }\end{array}$ & $+v e$ & $\begin{array}{l}+v e \\
+v e\end{array}$ & $\begin{array}{l}+v e \\
+v e\end{array}$ & $\begin{array}{l}+v e \\
+v e\end{array}$ & $\begin{array}{l}+v e \\
+v e\end{array}$ & $+v e$ \\
\hline
\end{tabular}

The values are represented as means \pm SD

The values with the same letters are non-significant at $\mathrm{p} \leq 5$

1: Conventional fractionation of pure palm olein

2: Enhanced fractionation of pure palm olein

3: Conventional fractionation of modified palm olein

4: Innovative fractionation of modified palm olein

POL: palm olein PO: palm oil P S O: palm super olein PM F: palm mid fraction

LF: Liquid fraction SF: Solid fraction +ve: positive

Egypt.J.Chem. 61, No.1 (2018) 
TABLE 2. Chemical properties of LF (SPO) and SF (PMF) produced by modified and conventional fractionation methods.

\begin{tabular}{|c|c|c|c|c|c|c|c|}
\hline \multirow[b]{2}{*}{ Characteristics } & & \multirow{2}{*}{$\begin{array}{c}\text { Original } \\
\text { POL } \\
\text { (Zero time) }\end{array}$} & \multicolumn{2}{|c|}{ Original POL } & \multicolumn{2}{|c|}{$\begin{array}{l}\text { Modified Blend } \\
(\mathrm{POL}+5 \% \mathrm{PO})\end{array}$} & \multirow[b]{2}{*}{$\begin{array}{c}\text { Modified } \\
\text { Blend }\end{array}$} \\
\hline & & & $\begin{array}{c}1 \\
\left(17^{\circ} \mathrm{C}\right)\end{array}$ & $\begin{array}{c}2 \\
\left(16.6^{\circ} \mathrm{C}\right)\end{array}$ & $\begin{array}{c}3 \\
\left(17^{\circ} \mathrm{C}\right) \\
\end{array}$ & $\begin{array}{c}4 \\
\left(16.6^{\circ} \mathrm{C}\right)\end{array}$ & \\
\hline \multirow{2}{*}{$\begin{array}{c}\text { Free fatty acid } \\
(\%)\end{array}$} & P S O & \multirow{2}{*}{$\begin{array}{c}0.15^{\mathrm{c}} \\
\pm 0.0071\end{array}$} & $\begin{array}{c}0.17^{\mathrm{ab}} \\
\pm 0.0071\end{array}$ & $\begin{array}{c}0.17^{\mathrm{b}} \\
\pm 0.011\end{array}$ & $\begin{array}{c}0.17^{\mathrm{b}} \\
\pm 0.0055\end{array}$ & $\begin{array}{c}0.18^{\mathrm{a}} \\
\pm 0.0044\end{array}$ & \multirow{2}{*}{$\begin{array}{c}0.15^{\mathrm{a}} \\
\pm 0.007\end{array}$} \\
\hline & P M F & & $\begin{array}{c}0.13^{\mathrm{b}} \\
\pm 0.011\end{array}$ & $\begin{array}{c}0.13^{\mathrm{b}} \\
\pm 0.011\end{array}$ & $\begin{array}{c}0.13^{\mathrm{b}} \\
\pm 0.007\end{array}$ & $\begin{array}{c}0.13^{\mathrm{b}} \\
\pm 0.007\end{array}$ & \\
\hline \multirow{2}{*}{$\begin{array}{l}\text { Peroxide value } \\
\qquad\left(\mathrm{meqo}_{2} / \mathrm{kg}\right)\end{array}$} & P S O & \multirow{2}{*}{$\begin{array}{c}3.4^{\mathrm{c}} \\
\pm 0.029\end{array}$} & $\begin{array}{c}3.6^{\mathrm{d}} \\
\pm 0.019\end{array}$ & $\begin{array}{c}3.62^{\mathrm{c}} \\
\pm 0.017\end{array}$ & $\begin{array}{c}3.61^{\mathrm{b}} \\
\pm 0.023\end{array}$ & $\begin{array}{c}3.80^{\mathrm{a}} \\
\pm 0.016\end{array}$ & \multirow{2}{*}{$\begin{array}{l}3.51^{\mathrm{a}} \\
\pm 0.03\end{array}$} \\
\hline & P M F & & $\begin{array}{l}3.33^{\mathrm{c}} \\
\pm 0.02\end{array}$ & $\begin{array}{l}3.36^{\mathrm{ab}} \\
\pm 0.05\end{array}$ & $\begin{array}{c}3.34^{\mathrm{bc}} \\
\pm 0.015\end{array}$ & $\begin{array}{c}3.39^{\mathrm{a}} \\
\pm 0.015\end{array}$ & \\
\hline \multirow{2}{*}{ Iodine value } & P S O & \multirow{2}{*}{$\begin{array}{c}56.5^{\mathrm{e}} \\
\pm 0.054\end{array}$} & $\begin{array}{c}60.8^{\mathrm{d}} \\
\pm 0.055\end{array}$ & $\begin{array}{c}61.6^{\mathrm{b}} \\
\pm 0.055\end{array}$ & $\begin{array}{c}61.0^{\mathrm{c}} \\
\pm 0.033\end{array}$ & $\begin{array}{c}64.8^{\mathrm{a}} \\
\pm 0.055\end{array}$ & \multirow{2}{*}{$\begin{array}{c}56.4^{\mathrm{a}} \\
\pm 0.055\end{array}$} \\
\hline & P M F & & $\begin{array}{c}43.9^{\mathrm{e}} \\
\pm 0.084\end{array}$ & $\begin{array}{l}45.2^{\mathrm{c}} \\
\pm 0.18\end{array}$ & $\begin{array}{l}44.1^{\mathrm{d}} \\
\pm 0.15\end{array}$ & $\begin{array}{l}47^{\mathrm{e}} \\
\pm 0.1\end{array}$ & \\
\hline \multirow{2}{*}{$\begin{array}{l}\text { Induction period } \\
\text { at } 100^{\circ} \mathrm{C} \text { by } \\
\text { Rancimat (h) }\end{array}$} & P S O & $\begin{array}{c}38.5^{\mathrm{a}} \\
\pm 0.089\end{array}$ & $\begin{array}{c}38.3^{\mathrm{b}} \\
\pm 0.044\end{array}$ & $\begin{array}{c}38.3^{\mathrm{b}} \\
\pm 0.084\end{array}$ & $\begin{array}{l}38.3^{\mathrm{ab}} \\
\pm 0.11\end{array}$ & $\begin{array}{c}38.1^{\mathrm{c}} \\
\pm 0.055\end{array}$ & \multirow[t]{2}{*}{$\begin{array}{c}38.6^{\mathrm{d}} \\
\pm 0.089\end{array}$} \\
\hline & P M F & & - & - & - & - & \\
\hline
\end{tabular}

The values with the same letters are non-significant at $\mathrm{p} \leq 5$

1: Conventional fractionation of pure palm olein

2: Enhanced fractionation of pure palm olein

3: Conventional fractionation of modified palm olein

4: Innovative fractionation of modified palm olein

POL: palm olein PO: palm oil P S O: palm super olein P M F: palm mid fraction

LF: Liquid fraction SF: Solid fraction

addition, the ratio between unsaturated: saturated fatty acids was $(1: 1)$ as mentioned by Teah[23].

Fatty acid profiles of palm olein and its fractions

Fatty acid compositions of original and modified POL fractions compared to conventional method are shown in Table 3. The most predominate FA's in original POL were oleic (42.24) and palmitic (39.6). In modified fractionation (temp. $16.6^{\circ} \mathrm{C}$ ), it was found that palmiticacid is 41.29 PMF2compared to 41.24 PMF1 whereas, it decreased in LF; POS1 and PSO2.Concerning oleic acid it was increased in modified fractionation $\left(16.6^{\circ} \mathrm{C}\right)$ amounted to 47.63 in PSO2 compared to the 47.2 in PSO1 (conventional method). In another way of modification applied with an addition of 5\% PO, lead to decreasing in palmitic acid in LF from 39.62 (modified POL) to $33.11 \& 32.64$ in PSO3 $\&$ PSO 4 and increasing in oleic acid from 42.21 to $47.27 \& 48.19$ respectively.

In the solid fraction, palmitic acid increased and oleic acid decreased in PMF3 \& PMF4. Concerning the amount of linoleic acid (18:2), it was found that significant decreasein all solid fractions namely PMF1, PMF2, PMF3 and PMF4(modified and conventional method). Whereas, when the addition of 5\% PO to POL, no significant change in the linolenic (18:3) content.

The proportions of SFA, USFA, and PUFA for PSO show variations in their amounts. It was also found that in solid fraction (PMF1, PMF2, PMF3 and PMF4), showed increasing in the SFA and decreasing in MUSFA in both samples prepared by conventional and modified methods (Table 3 ). Whereas SFA decreased and MUSFA increased in liquid fractions, namely PSO1, PSO2, PSO3 \& PSO4.

The Proportion of PUFA increased in modified temperature treated samples in comparison to those prepared by conventional method in LF, whereas no significant changes in case of solid fractions. When adding 5\% PO, the PUFA increase in PSO3 \& PSO4, whereas a decrease in PMF3 \& PMF4 is obtained. 
TABLE 3. Fatty acids composition of LF (SPO) and SF (PMF) produced by modified and conventional fractionation methods.

\begin{tabular}{|c|c|c|c|c|c|c|c|}
\hline \multirow{2}{*}{ Characteristics } & & \multirow{2}{*}{$\begin{array}{c}\text { Original } \\
\text { POL } \\
\text { (Zero time) }\end{array}$} & \multicolumn{2}{|c|}{ Original POL } & \multicolumn{2}{|c|}{$\begin{array}{l}\text { Modified Blend } \\
(\text { POL }+5 \% \text { PO) }\end{array}$} & \multirow{2}{*}{$\begin{array}{l}\text { Modified } \\
\text { Blend } \\
\text { (Zero } \\
\text { time) }\end{array}$} \\
\hline & & & $\begin{array}{c}1 \\
\left(17^{\circ} \mathrm{C}\right)\end{array}$ & $\begin{array}{c}2 \\
\left(16.6^{\circ} \mathrm{C}\right)\end{array}$ & $\begin{array}{c}3 \\
\left(17^{\circ} \mathrm{C}\right)\end{array}$ & $\begin{array}{c}4 \\
\left(16.6^{\circ} \mathrm{C}\right)\end{array}$ & \\
\hline \multirow{2}{*}{$\begin{array}{l}\text { Lauric acid } \\
\quad \text { C 12:0 }\end{array}$} & P S O & \multirow{2}{*}{$\begin{aligned} & 0.44^{\mathrm{a}} \\
\pm & 0.0071\end{aligned}$} & $\begin{array}{c}0.41^{\mathrm{c}} \\
\pm 0.0071\end{array}$ & $\begin{array}{c}0.38^{\mathrm{d}} \\
\pm 0.011\end{array}$ & $\begin{array}{c}0.40^{\mathrm{b}} \\
\pm 0.009\end{array}$ & $\begin{array}{c}0.30^{\mathrm{e}} \\
\pm 0.014\end{array}$ & \multirow{2}{*}{$\begin{array}{c}0.44^{\mathrm{b}} \\
\pm 0.007\end{array}$} \\
\hline & P M F & & $\begin{array}{c}0.46^{\mathrm{a}} \\
\pm 0.009\end{array}$ & $\begin{array}{c}0.46^{\mathrm{a}} \\
\pm 0.011\end{array}$ & $\begin{array}{c}0.46^{\mathrm{a}} \\
\pm 0.008\end{array}$ & $\begin{array}{c}0.45^{\mathrm{ab}} \\
\pm 0.005\end{array}$ & \\
\hline \multirow{2}{*}{$\begin{array}{l}\text { Myristic acid } \\
\quad \text { C 14:0 }\end{array}$} & P S O & \multirow{2}{*}{$\begin{array}{c}1.33^{\mathrm{a}} \\
\pm 0.011\end{array}$} & $\begin{array}{c}1.30^{\mathrm{b}} \\
\pm 0.011\end{array}$ & $\begin{array}{c}1.24^{\mathrm{d}} \\
\pm 0.013\end{array}$ & $\begin{array}{c}1.28^{\mathrm{c}} \\
\pm 0.002\end{array}$ & $\begin{array}{c}1.05^{\mathrm{e}} \\
\pm 0.013\end{array}$ & \multirow{2}{*}{$\begin{array}{c}1.34^{\mathrm{ab}} \\
\pm 0.011\end{array}$} \\
\hline & P M F & & $\begin{array}{c}1.33^{\mathrm{a}} \\
\pm 0.008\end{array}$ & $\begin{array}{c}1.33^{\mathrm{ab}} \\
\pm 0.004\end{array}$ & $\begin{array}{c}1.32^{\mathrm{b}} \\
\pm 0.004\end{array}$ & $\begin{array}{c}1.32^{\mathrm{b}} \\
\pm 0.007\end{array}$ & \\
\hline \multirow{2}{*}{$\begin{array}{l}\text { palmitic acid } \\
\text { C 16:0 }\end{array}$} & P S O & \multirow{2}{*}{$\begin{array}{l}39.60^{\mathrm{a}} \\
\pm 0.011\end{array}$} & $\begin{array}{l}33.20^{\mathrm{b}} \\
\pm 0.011\end{array}$ & $\begin{array}{l}32.95^{\mathrm{d}} \\
\pm 0.013\end{array}$ & $\begin{array}{l}33.11^{\mathrm{c}} \\
\pm 0.009\end{array}$ & $\begin{array}{l}32.64^{\mathrm{e}} \\
\pm 0.071\end{array}$ & \multirow{2}{*}{$\begin{array}{l}39.62^{\mathrm{e}} \\
\pm 0.011\end{array}$} \\
\hline & P M F & & $\begin{array}{l}41.42^{\mathrm{a}} \\
\pm 0.008\end{array}$ & $\begin{array}{l}41.29^{\mathrm{c}} \\
\pm 0.013\end{array}$ & $\begin{array}{l}41.39^{\mathrm{b}} \\
\pm 0.005\end{array}$ & $\begin{array}{l}41.21^{\mathrm{d}} \\
\pm 0.013\end{array}$ & \\
\hline \multirow{2}{*}{$\begin{array}{l}\text { Stearic acid } \\
\quad \text { C 18:0 }\end{array}$} & P S O & \multirow{2}{*}{$\begin{array}{c}4.47^{\mathrm{a}} \\
\pm 0.011\end{array}$} & $\begin{array}{c}3.42^{\mathrm{b}} \\
\pm 0.012\end{array}$ & $\begin{array}{c}3.24^{\mathrm{d}} \\
\pm 0.018\end{array}$ & $\begin{array}{c}3.40^{\mathrm{c}} \\
\pm 0.002\end{array}$ & $\begin{array}{c}2.95^{\mathrm{e}} \\
\pm 0.009\end{array}$ & \multirow{2}{*}{$\begin{array}{c}4.49^{\mathrm{e}} \\
\pm 0.011\end{array}$} \\
\hline & P M F & & $\begin{array}{c}5.66^{\mathrm{a}} \\
\pm 0.004\end{array}$ & $\begin{array}{c}5.54^{\mathrm{c}} \\
\pm 0.005\end{array}$ & $\begin{array}{c}5.64^{\mathrm{b}} \\
\pm 0.016\end{array}$ & $\begin{array}{c}5.41^{\mathrm{d}} \\
\pm 0.005\end{array}$ & \\
\hline \multirow{2}{*}{$\begin{array}{l}\text { Oleic acid } \\
\text { C } 18: 1\end{array}$} & P S O & \multirow{2}{*}{$\begin{array}{l}42.24^{\mathrm{e}} \\
\pm 0.011\end{array}$} & $\begin{array}{l}47.20^{\mathrm{d}} \\
\pm 0.04\end{array}$ & $\begin{array}{l}47.63^{\mathrm{b}} \\
\pm 0.016\end{array}$ & $\begin{array}{l}47.27^{\mathrm{c}} \\
\pm 0.013\end{array}$ & $\begin{array}{l}48.19^{\mathrm{a}} \\
\pm 0.021\end{array}$ & \multirow{2}{*}{$\begin{array}{l}42.21^{\mathrm{a}} \\
\pm 0.011\end{array}$} \\
\hline & P M F & & $\begin{array}{c}39.55^{\mathrm{e}} \\
\pm 0.004\end{array}$ & $\begin{array}{l}39.76^{\mathrm{c}} \\
\pm 0.004\end{array}$ & $\begin{array}{l}39.59^{\mathrm{d}} \\
\pm 0.011\end{array}$ & $\begin{array}{l}39.84^{\mathrm{b}} \\
\pm 0.008\end{array}$ & \\
\hline \multirow{2}{*}{$\begin{array}{l}\text { Linoleic acid } \\
\text { C } 18: 2\end{array}$} & P S O & \multirow{2}{*}{$\begin{array}{l}11.22^{\mathrm{e}} \\
\pm 0.011\end{array}$} & $\begin{array}{l}13.80^{\mathrm{d}} \\
\pm 0.023\end{array}$ & $\begin{array}{l}14.15^{\mathrm{b}} \\
\pm 0.009\end{array}$ & $\begin{array}{l}13.87^{\mathrm{c}} \\
\pm 0.009\end{array}$ & $\begin{array}{r}14.54^{\mathrm{a}} \\
\pm 0.014\end{array}$ & \multirow{2}{*}{$\begin{array}{r}11.20^{\mathrm{a}} \\
\pm 0.011\end{array}$} \\
\hline & P M F & & $\begin{array}{l}10.90^{\mathrm{a}} \\
\pm 0.015\end{array}$ & $\begin{array}{l}10.95^{\mathrm{c}} \\
\pm 0.011\end{array}$ & $\begin{array}{l}10.92^{\mathrm{d}} \\
\pm 0.008\end{array}$ & $\begin{array}{l}11.10^{\mathrm{b}} \\
\pm 0.011\end{array}$ & \\
\hline \multirow{2}{*}{$\begin{array}{l}\text { Linolenic acid } \\
\text { C } 18: 3\end{array}$} & P S O & \multirow{2}{*}{$\begin{array}{c}0.22^{\mathrm{b}} \\
\pm 0.011\end{array}$} & $\begin{array}{c}0.21^{\mathrm{b}} \\
\pm 0.008\end{array}$ & $\begin{array}{c}0.23^{\mathrm{b}} \\
\pm 0.011\end{array}$ & $\begin{array}{c}0.21^{\mathrm{b}} \\
\pm 0.008\end{array}$ & $\begin{array}{c}0.25^{\mathrm{a}} \\
\pm 0.015\end{array}$ & \multirow{2}{*}{$\begin{array}{l}0.22^{\mathrm{a}} \\
\pm 0.01\end{array}$} \\
\hline & P M F & & $\begin{array}{c}0.20^{\mathrm{a}} \\
\pm 0.008\end{array}$ & $\begin{array}{c}0.20^{\mathrm{a}} \\
\pm 0.008\end{array}$ & $\begin{array}{c}0.20^{\mathrm{a}} \\
\pm 0.005\end{array}$ & $\begin{array}{c}0.20^{\mathrm{a}} \\
\pm 0.005\end{array}$ & \\
\hline \multirow{2}{*}{$\begin{array}{l}\text { Arachidic acid } \\
\text { C 20:0 }\end{array}$} & P S O & \multirow{2}{*}{$\begin{array}{c}0.48^{\mathrm{a}} \\
\pm 0.008\end{array}$} & $\begin{array}{c}0.46^{\mathrm{b}} \\
\pm 0.005\end{array}$ & $\begin{array}{c}0.18^{\mathrm{c}} \\
\pm 0.008\end{array}$ & $\begin{array}{c}0.46^{\mathrm{b}} \\
\pm 0.009\end{array}$ & $\begin{array}{c}0.08^{\mathrm{d}} \\
\pm 0.008\end{array}$ & \multirow{2}{*}{$\begin{array}{c}0.48^{\mathrm{a}} \\
\pm 0.008\end{array}$} \\
\hline & P M F & & $\begin{array}{c}0.48^{\mathrm{a}} \\
\pm 0.005\end{array}$ & $\begin{array}{c}0.47^{\mathrm{a}} \\
\pm 0.004\end{array}$ & $\begin{array}{c}0.48^{\mathrm{a}} \\
\pm 0.005\end{array}$ & $\begin{array}{c}0.47^{\mathrm{a}} \\
\pm 0.004\end{array}$ & \\
\hline Saturated fatty acids & $\begin{array}{l}\text { P S O } \\
\text { P M F }\end{array}$ & 46.32 & $\begin{array}{l}38.79 \\
49.35\end{array}$ & $\begin{array}{l}37.99 \\
49.09\end{array}$ & $\begin{array}{l}38.65 \\
49.29\end{array}$ & $\begin{array}{l}37.02 \\
48.86\end{array}$ & 46.37 \\
\hline $\begin{array}{l}\text { Unsaturated fatty } \\
\text { acids }\end{array}$ & $\begin{array}{l}\text { P S O } \\
\text { P M F }\end{array}$ & 53.68 & $\begin{array}{l}61.21 \\
50.65\end{array}$ & $\begin{array}{l}62.01 \\
50.91\end{array}$ & $\begin{array}{l}61.35 \\
50.71\end{array}$ & $\begin{array}{l}62.98 \\
51.14\end{array}$ & 53.63 \\
\hline MUSFA & P S O & 42.24 & 47.20 & 47.63 & 47.27 & 48.19 & 42.21 \\
\hline NIUSFA & PMF & 42.24 & 39.55 & 39.76 & 39.59 & 39.84 & 42.21 \\
\hline PUSFA & $\begin{array}{l}\text { P S O } \\
\text { P M F }\end{array}$ & 11.44 & $\begin{array}{l}14.01 \\
11.10\end{array}$ & $\begin{array}{l}14.38 \\
11.15\end{array}$ & $\begin{array}{l}14.08 \\
11.12\end{array}$ & $\begin{array}{l}14.79 \\
11.30\end{array}$ & 11.42 \\
\hline SFA/USFA & P S O & 086 & 0.63 & 0.61 & 0.63 & 0.59 & 086 \\
\hline SFA/USFA & P M F & 0.86 & 0.97 & 0.96 & 0.97 & 0.96 & 0.86 \\
\hline MUSFA/PUSFA & P S O & 369 & 3.37 & 3.31 & 3.36 & 3.26 & 370 \\
\hline MUSFA/PUSFA & P M F & 3.69 & 3.56 & 3.57 & 3.56 & 3.53 & 3.70 \\
\hline PUISFA/SFA & P S O & 025 & 0.36 & 0.38 & 0.36 & 0.40 & 025 \\
\hline & P M F & & 0.22 & 0.23 & 0.23 & 0.23 & 0.25 \\
\hline
\end{tabular}

Egypt.J.Chem. 61, No.1 (2018) 
Table 3 shows the GLC analysis of fatty acids of palm olein, palm super olein and palm mid fractions obtained by dry fractionation technique. From Table 3, it was noticed that the fatty acid composition of the modified POL and pure POL samples were found to be nearly the same. Regarding to the liquid fractions (PSO), the major constituent unsaturated fatty acid (USFA) was oleic followed by linoleic acids. Whereas, linolenic acid was present in minor quantities in the four liquid fractions (Table 3). Concerning the SFA in the LF's, palmitic acid was the major constituent followed by stearic acid, whereas, lauric, myristic and arachidic acids are the minor constituents.

On the other hand, SFA of PMF(PMF1, PMF2, PMF3 and PMF4 obtained by dry fractionation of palm olein) were calculated (Table 3). Thus, Lauric and myristic acids were present in similar minor quantities in both PMF1 and PMF2 $(0.46 \%, 1.33 \%)$ whereas they were $0.46 \%, 1.32$ $\%$ in PMF3 and $0.45,1.32 \%$ in PMF4. While palmitic and stearic acids were detected in PMF1 amounted to $41.42 \%$, 5.66\%; in PMF2 $41.29 \%$, $5.54 \%$ and $41.39 \%, 5.64 \% 41.21 \%, 5.41 \%$ in PMF3 and PMF4 respectively. From Table 3 it can be seen that no variation in levels of arachidic acid (C20:0) in the four samples.

Regarding unsaturated fatty acids (USFA), namely, oleic, linoleic and linolenic acids, it is clear that oleic acid was the most prevalent unsaturated fatty acid in all samples. Linoleic acid was the second major unsaturated fatty acid which presents in all PMF in similar amounts. Whereas, linolenic acid was detected in similar minute amounts in all PMF samples $(0.2 \%)$. These results are in harmony with those of JiePeng et al., [24], as they reported that low temperature brings the directional suspended crystal separation which decreased the separating efficiency and purity of the products and mixed the crystals with a large number of low melting compositions. As shown in Table 3 the amounts of SFA and USFA in olein samples were nearly similar $(46.32 \%, 53.68 \%$ in pure POL and $46.37 \%, 53.63 \%$ in modified PO). In addition, the amounts of USFA were much higher than that in all fractions (PMF`s). It was also found that PSO fractionated at lower temperatures contained less SFA, more USFA than PSO fractionated at a higher temperature. These results are in agreement with that reported by Hasmadi et al., [25].
Fractionation by the traditional method at $17^{\circ} \mathrm{C}$ resulted in the highest super palm olein yield but with low oleic acid content. While DF at relatively lower crystallization temperature $\left(16.6^{\circ} \mathrm{C}\right)$ showed a considerable effect on the fatty acid composition of liquid fractions as well as IV, MP and CT in comparison with that at higher crystallization temperature $\left(17^{\circ} \mathrm{C}\right)$.

\section{Conclusion}

Contributing to the sustainable development of palm oil industry via identifying and addressing some hot spots. The dry fractionation technology (simplest and cheapest process) starts new possibilities of applications by reducing crystallization temperature (modified treatment $16.6^{\circ} \mathrm{C}$ ) and innovative method by adding $5 \% \mathrm{PO}$ for improving the seeding process $\left(16.6^{\circ} \mathrm{C}\right)$. These industrial modifications revealed that the physical and chemical properties of the palm olein fractions have positive effects. So, the production of PSO with IV of more than 62 with good oxidative stability, cold stability and low cloud point would require a proper cooling profile and good separation. The obtained PSO by fractionation using modified olein $(95 \%$ palm olein \& $5 \%$ palm oil) at $16.6^{\circ} \mathrm{C}$ gave $\mathrm{PSO}$ with MP $9^{\circ} \mathrm{C}$ and also enhanced the cloud point; melting point and iodine value.

It is recommended that the modified and innovative dry fractionation process performed in large-scale, can be taken as a model for improving palm oil fractionation.

\section{Acknowledoment}

The authors would like to thank Ajwaa Company for Food Industries, Attaka, Suez, Egypt for their kind cooperation.

\section{References}

1. Dijkstra A. J., Chapter 12; Fractionation, in Book: Edible Oil Processing from a Patent Perspective. Springer New York Heidelberg Dordrecht London. Library of Congress Control Number: 2012936065 (2013).

2. Timms R.E., Principles of Fat Fractionation (Society of Chemical Industry lecture Paper Series, Paper No. 0039), Society of Chemical Industry, London, UK (1994).

3. Calliauw G., Fredrick F., Gibon V., De Greyt W., Wouters J., Foubert I. and Dewettinck K., On the fractional crystallization of palm olein: Solid

Egypt.J.Chem. 61 , No.1 (2018) 
solutions and eutectic solidification. Food Res. Int., 43, 972-981 (2010).

4. Hamm W., Trends in edible oil fractionation. Trends in Food Science \& Technology. 6(4), 121$126(1995)$

5. Timms, R. E., Fractional crystallization the fat modification process for the $21^{\text {st }}$ century. Eur. $J$. Lipid Sci. Technol., 107(1), 48- 57 (2005).

6. Abdel-Razek A.G., Hassanein M.M.M., Rudzińska M. and El-Mallah M.H., Role of minor constituents and balanced fatty acids in upgrading the low stability of cooking oils blended with palm super olein. Asian Journal of Scientific Research, 10, 150-159 (2017).

7. Rudzińska M., Hassanein M.M.M., Abdel-Razek A. G., Kmiecik D., Siger A. and Ratusz K., Influence of composition on degradation during repeated fat-frying of binary and ternary blends of palm, sunflower and soybean oils with health optimised saturated to unsaturated fatty acid ratios. International Journal of Food Science and Technology (2017). Version of Record online: 10 NOV 2017, DOI: 10.1111/ijfs.13678.

8. Omar Z., Hishamuddin E., Sahri M. M., Fauzi S. H. M., Dian N. L. H. M., Ramli M. R. and AbdRashid N., Palm oil crystallization: A review. Journal of Oil Palm Research. 27(2), 97-106 (2015).

9. Idris N. A., Jamaludin R. and Hassan H., Process to prevent and delay clouding in palm olein. US Patent No. 20030068426 A1 (2003)

10. Hashimoto S., Nezu T., Arakawa H., Ito T. and Maruzeni S., Preparation of sharp-melting hard palm midfraction and its use as hard butter in chocolate. J. Am. Oil Chem. Soc., 78, 455-460 (2001).

11. Krishnamurthy R. and Kellens M.Fractionation and winterization. In: Bailey's Industrial Oil and Fat Products, Volume 4, Edible Oil and Fat Products: Processing Technology, pp. 301-337 (Y.H. Hui (ed.), John Wiley, Champaign, USA) (1996).

12. AOCS Official methods and recommended practices of the american oil chemists' society. Champaign: AOCS Press. Capannesi et al., 2000. C (1993).

13. AOCS Official Method Cd 12b-92 Oil stability index. Sampling and analysis of commercial fats and oils. Methods And Recommended Practices Of The American Oil Chemists' Society, $4^{\text {th }}$ ed., American Oil Chemists' Society, USA (1997).

14. AOCS American Oil Chemists' Society. Official Method Ce 1k-07. Direct methylation of lipids for the determination of total fat, saturated, cismonounsaturated, cis-polyunsaturated, and trans fatty acids by chromatography. Official Methods and Recommended Practices of the American Oil Chemists' Society, $5^{\text {th }}$ d., USA (2007).

15. Calliauw G., Gibon V., Greyt W. De., Plees L., Foubert I. and Wettinck K. D., Phase composition during palm olein fractionation and its effect on soft PMF and super olein quality. J. Am. Oil Chem. Soc. 84, 885-891 (2007).

16. Ablatip R., Yee-Ying Lee, Teck-Kim Tang, EngTong Phuah, Choon-Min Lee, Chin-Ping Tan and Oi-Ming Lai, Palm-based diacylglycerol fat dry fractionation: effect of crystallisation temperature, cooling rate and agitation speed on physical and chemical properties of fractions. Peer $J$ 1:e72 (2013); DOI 10.7717/peerj.72.

17. Kellens marc, Gibon Veronique Hendrix marc and De greytwim, Palm oil fractionation. Eur. J. Lipid Sci. Technol. 109, 336- 349 (2007).

18. Arnaud E, Collignan A. Chicken fat dry fractionation: effect of temperature and time on crystallization, filtration and fraction properties. European Journal of Lipids Science And Technology 110, 239-244 (2008).

19. Zaliha O., Chong C.L., Cheow C. S., Norizzah A.R. and Kellens M.J., Crystallization properties of palm oil by dry fractionation. Food Chemistry 86, 245-250 (2004).

20. Deffense, E., Fractionation of palm oil. J. Amer. Oil Chem. Soc. 62 (2), 376-385 (1985).

21. Dang L., Li S., Zhang H., Si Y., Wang Z. Crystallization behavior of palm kernel oil monitored by in-situ Focused Beam Reflectance Measurement (FBRM) and Particles Video Microscope (PVM) during suspension crystallization. Advances in Materials Physics and Chemistry 5, 31-38 (2015).

22. El-Samanody, M. K. Biochemical evaluation of Egyptian rapeseed oil comparing with palm oil. Ph. D. Thesis, Fac. of Agric., Zagazig Univ (1998).

Egypt.J.Chem. 61, No.1 (2018) 
23. Teah, Y. K., Improvements in the frying quality of vegetable oils by blending with palm olein. Second Arab Conference, A. R. E., Cairo (1993).

24. Jie Peng, Xue Bai, Yunzhu Zhang, Xingpeng Bai, Directional crystallization kinetics of coconut oil under temperature gradient. Global journal of science frontier research chemistry. 12 (4) 1.0 (2012).
25. Hasmadi M., Aini I. N., Mamot S. and Yusef M. S. A., The effect of different types of stirrer and fractionation temperatures during fractionation on the yield characteristics and quality of oleins. Journal of Food Lipids, 9 (4), 295- 307 (2002).

(Received 12/ 12 /2017; accepted $30 / 1 / 2018)$

\section{إنتاج زيت سبوبر أوليين النخيل على المستوى الصناعى بإستخدام طريقة معدلة ومبتكرة

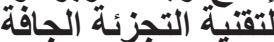

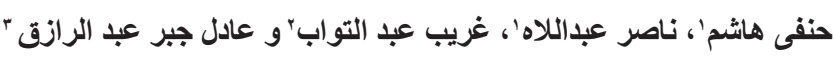

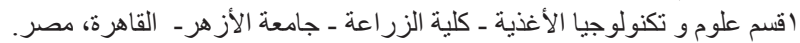

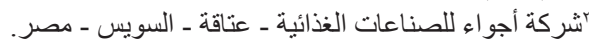

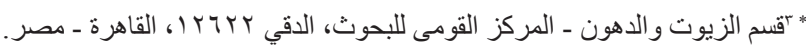

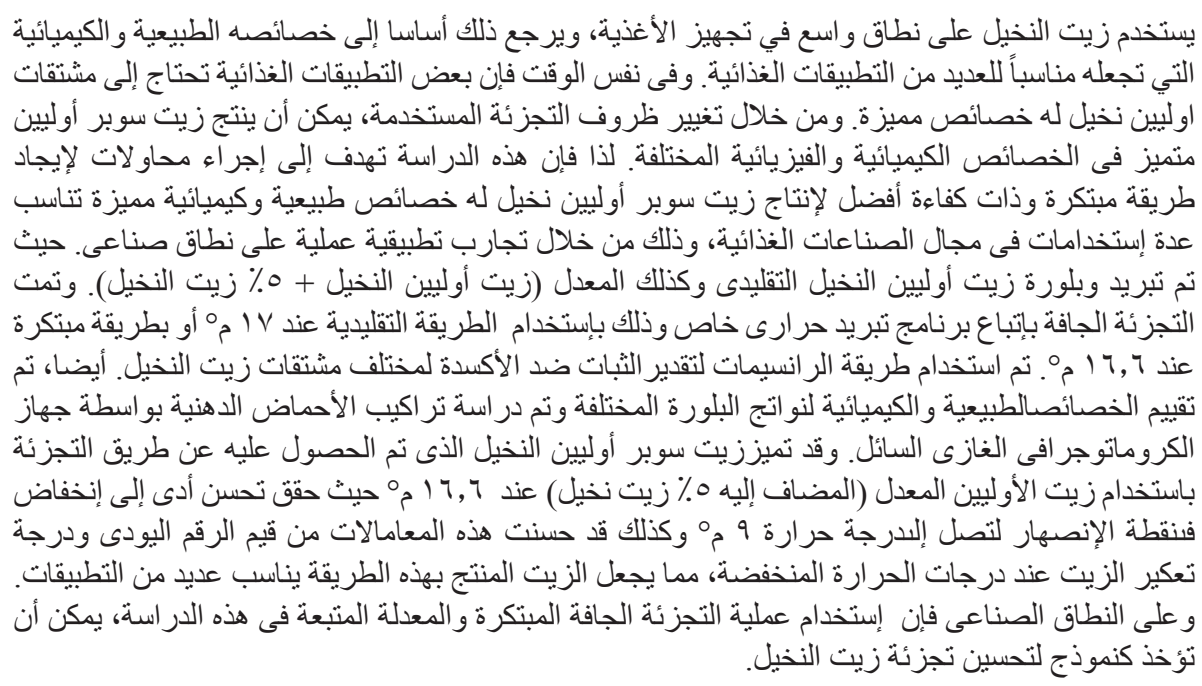

